\title{
Kontroversi Ujian Nasional Sepanjang Masa
}

\author{
Suke Silverius \\ sukesilver@yahoo.com
}

\begin{abstract}
Abstrak: Keberadaan dan penerapan UN menuai kritik dan kontroversi apabila dikaitkan dengan UU Sisdiknas Nomor 20, Tahun 2003 tentang Sistem Pendidikan Nasional (Sisdiknas). Rangkaian butir-butir kritik itu terjalin dalam tujuh untaian pelanggaran UN yakni hanya mengukur aspek kognitif sehingga tidak dapat dijadikan standar untuk mengukur mutu pendidikan, mengabaikan diversifikasi potensi daerah dan peserta didik, merampas hak guru untuk melakukan evaluasi hasil belajar peserta didiknya, mendasarkan evaluasi pada peserta didik semata, penentuan kelulusan bukan oleh guru, pemerintah dan pemerintah daerah merampas hak pemberian ijazah kepada peserta didik setelah lulus ujian. UN hanya mengevaluasi hasil akhir proses pembelajaran secara momental dan tidak komprehensif serta mengabaikan orientasi tujuan pendidikan sehingga tidak mengindikasikan mutu pendidikan. Paparan kontroversi ini dimaksudkan untuk dimanfaatkan para pendidik dan pemerhati pendidikan guna menemukan solusi dalam rangka pembenahan kebijakan penilaian pendidikan demi peningkatan pendidikan yang berakses pada pembangunan nasional bangsa menuju bertambahnya kesejahteraan rakyat.
\end{abstract}

Kata Kunci: kontroversi, ujian nasional, pembenahan, kebijakan

\begin{abstract}
The existence and application of National Examination initiate critics and controversies correlated with the National Education System Act Number 20, Year 2003 about the National Education System. The set of Critics is composed of seven disagreements linked with the national examination matter which are appraising the cognitive aspects only with the result that it cannot be used as a standard made to measure up education quality, disregarding the diversification of regional potency and of students competence, taking away the teachers' right to do the evaluation of students achievement, establishing the evaluation based merely on the students, determining the passing grade of the examination in the absence of teachers, national and regional government take away the right of teachers in giving the diploma to the graduate students. National examination evaluates the only process of momentary and incomprehensive learning activity and at the same time neglecting educational goal orientation that brings to an end without indicating the education quality. Explication of these controversies is aimed at providing teachers and education observers the prospect of the solutions in terms of educational evaluation policy improvement for the sake of the education enhancement that have access to national development for the augmentation of people's prosperity.
\end{abstract}

Key Words: controversy, national examination, improvement, policy.

\section{Pendahuluan}

Keberadaan dan penerapan alat evaluasi hasil belajar akhir jenjang pendidikan yang belakangan ini disebut ujian nasional (UN), menuai kritik dan kontroversi yang senantiasa berlarut. Kontroversi seputar UN semakin mencuat dengan terbitnya UU Sisdiknas Nomor 20, Tahun 2003 tentang Sistem Pendidikan Nasional (Sisdiknas). Dalam penyelenggaraan UN terdapat tindakan-tindakan yang tidak dapat dipertanggungjawabkan secara akademik dan yuridis atas dasar undang-undang tersebut. Oleh sebab itu, diperlukan suatu kajian ilmiah untuk menilai dan mencarikan solusi atas kritik dan kontroversi tersebut.

Rangkaian butir-butir kritik itu terjalin dalam tujuh untaian. Pertama, UN hanya mengukur satu aspek kompetensi kelulusan yakni aspek kognitif padahal menurut penjelasan pasal 35 ayat 1 UU Sisdiknas, kompetensi lulusan seharusnya mencakup tiga aspek yaitu aspek sikap (afektif), pengetahuan (kognitif), dan keterampilan (psikomotorik). Dengan demikian, kebijakan UN yang hanya mengukur aspek kognitif tidak dapat dijadikan standar untuk mengukur mutu pendidik- 
an. Kedua, penilaian yang dilakukan dalam UN tidak memperhatikan keragaman potensi daerah dan peserta didik. Menurut Pasal 36 ayat 2 UU Sisdiknas, kurikulum harus dikembangkan dengan prinsip diversifikasi (kemajemukan) sesuai dengan satuan pendidikan, potensi daerah, dan peserta didik, namun kebijakan tersebut diabaikan UN dengan melakukan penilaian pendidikan tanpa memperhatikan keberagaman potensi daerah dan peserta didik. Ketiga, hak guru untuk melakukan evaluasi hasil belajar peserta didiknya diambil alih oleh pemerintah dengan diberlakukannya UN. Hal ini melanggar Pasal 39 ayat 2 UU Sisdiknas yang menyatakan bahwa "Pendidik merupakan tenaga profesional yang bertugas merencanakan dan melaksanakan pro-ses pembelajaran, menilai hasil pembelajaran..." Keempat, dalam kaitannya dengan mutu pendidikan, UN hanya melakukan evaluasi terhadap peserta didik sedangkan menurut Pasal 57 ayat 2 UU Sisdiknas, mutu pendidikan seharusnya didasarkan pada evaluasi yang dilakukan terhadap peserta didik, lembaga, dan program pendidikan. Kelima, Pasal 58 ayat 1 UU Sisdiknas, "Evaluasi hasil belajar peserta didik dilakukan oleh pendidik untuk memantau proses, kemajuan, dan perbaikan hasil belajar peserta didik secara berkesinambungan". Menurut pasal 58 ayat UU Sisdiknas, evaluasi hasil belajar dan penentuan kelulusan peserta didik dilakukan oleh pendidik/guru dan satuan pendidikan/sekolah. Kewenangan pendidik/guru dan sekolah termaksud telah dirampas melalui pelaksanaan UN. Keenam, ditegaskan lebih lanjut bahwa kewenangan pemerintah dan pemerintah daerah melakukan evaluasi menurut Pasal 59 ayat 1 UU Sisdiknas dapat dilakukan terhadap pengelola satuan, jalur, jenjang dan jenis pendidikan, dan bukan evaluasi terhadap hasil belajar peserta didik. Ketujuh, Pasal 61 ayat 2 UU Sisdiknas menyatakan, " Ijazah diberikan kepada peserta didik sebagai pengakuan terhadap prestasi belajar dan/atau penyelesaian suatu jenjang pendidikan setelah lulus ujian yang diselenggarakan oleh satuan pendidikan yang terakreditasi". Kewenangan pendidik/guru dan sekolah termaksud telah dirampas melalui pelaksanaan UN.

Kajian hukum tersebut di atas ditunjang pula oleh kajian sosial-pedagogik dengan menge- depankan prinsip Evaluasi Pendidikan menurut UU Sisdiknas yang mengutamakan penilaian secara komprehensif, sedangkan prinsip evaluasi UN hanya mengutamakan hasil akhir pembelajaran daripada proses pembelajaran sehingga dapat mengakibatkan terjadinya disorientasi tujuan pendidikan. Disinyalir bahwa UN ternyata hanya menguntungkan sekelompok kecil peserta didik yang mampu secara finansial memperoleh akses untuk lulus.

Dengan penilaiannya yang sangat terbatas, UN tidak akan memperlihatkan mutu pendidikan. Apalagi jika kelulusan peserta didik hanya didasarkan atas hasil UN yang momental dan tidak komprehensif, maka UN menjadi sangat kejam karena ratusan ribu peserta didik akan menjadi korban kebijakan yang salah.

UN menimbulkan berbagai permasalahan karena pelanggaran terhadap ketentuan UU Sisdiknas. Kontroversi UN memperlihatkan tiadanya taat asas pemerintah yang berseberangan dengan kepatuhan masyarakat umumnya dan sekolah khususnya terhadap penyelenggaraan UN. Mengapa dibiarkan pelaksanaan UN yang mengabaikan pengukuran mutu pendidikan tetapi hanya mengukur aspek kognitif semata padahal seharusnya mencakup tiga aspek yaitu aspek sikap (afektif), pengetahuan (kognitif), dan keterampilan (psikomotorik)? Mengapa UN diperkenankan melakukan penilaian pendidikan tanpa memperhatikan keberagaman potensi daerah dan peserta didik? Apa alasan pemerintah merampas hak guru untuk melakukan evaluasi hasil belajar peserta didiknya, menentukan kelulusan, memberi ijazah, dan memantau proses, kemajuan, dan perbaikan hasil belajar peserta didik secara berkesinambungan? Di manakah letak keadilan apabila proses belajar yang komprehensif berkelanjutan dievaluasi melalui UN yang yang momental dan tidak komprehensif dengan mengorbankan ratusan ribu peserta didik terhadap kebijakan yang salah tersebut? Oleh sebab itu, tujuan tulisan ini ialah memaparkan kontroversi termaksud berikut untaian permasalahannya agar dapat dimanfaatkan para pendidik dan pemerhati pendidikan guna menemukan solusi demi menegakkan hukum dan perbaikan pendidikan di tanah air. 


\section{Kajian Literatur}

UN merupakan salah satu jenis penilaian yang diselenggarakan pemerintah guna mengukur keberhasilan peserta didik yang telah menyelesaikan jenjang pendidikan pada jalur sekolah/ madrasah yang diselenggarakan secara nasional. Kehadiran UN telah menjadi perdebatan dan kontroversi berkesinambungan di tengah masyarakat. Di satu pihak ada yang setuju, karena dianggap dapat meningkatkan mutu pendidikan. Fokus pembelajaran ditujukan pada keberhasilan peserta didik mengikuti UN. Paradigma model pembelajaran digeser ke arah pembelajaran yang lebih berorientasi pada pencapaian kemampuan kognitif. Para guru lebih gandrung pada model-model pembelajaran gaya lama yang lebih menekankan usaha untuk pencapaian kemampuan kognitif siswa, melalui gaya pembelajaran tekstual dan behavioristik.

Guna mempersiapkan UN, sekolah dan guru dipacu untuk dapat memberikan pelayanan sebaik-baiknya agar para siswa dapat mengikuti ujian dan memperoleh hasil ujian yang sebaikbaiknya. Demikian juga siswa didorong untuk belajar secara sungguh-sungguh agar bisa lulus dengan hasil yang sebaik-baiknya. Bimbingan belajar secara individual atau pun klasikal (kelompok) diikuti guna mendapat hasil UN yang memuaskan. Sementara, di pihak lain juga tidak sedikit yang merasa berkeberatan karena menganggap bahwa UN sebagai sesuatu yang sangat berseberangan dengan semangat reformasi pembelajaran yang sedang dikembangkan. Paradigma model pembelajaran lebih berorientasi pada pencapaian kemampuan afektif dan psikomotor, melalui strategi dan pendekatan pembelajaran yang jauh lebih menyenangkan dan kontekstual, dengan berangkat dari teori belajar konstruktivisme.

Kontroversi seputar UN berakar dari berbagai pelanggaran terhadap UU Sisdiknas Nomor 20, Tahun 2003 tentang Sistem Pendidikan Nasional (Sisdiknas) berupa tindakan-tindakan yang bertentangan secara akademik dan yuridis atas dasar undang-undang tersebut. Beberapa pelanggaran disajikan berupa untaian butir-butir kritik sebagai materi bahasan yang akan dijadikan dasar untuk mencarikan solusinya. Pertama, kenyataan menunjukkan bahwa UN hanya mengukur aspek kognitif yang hasilnya dipakai sebagai penentu kelulusan kompetensi siswa. Hal ini bertentangan dengan penetapan kompetensi lulusan menurut UU Sisdiknas. Padahal menurut penjelasan pasal 35 ayat 1 UU Sisdiknas, kompetensi lulusan seharusnya mencakup tiga aspek yaitu aspek sikap (afektif), pengetahuan (kognitif), dan keterampilan (psikomotorik). Dengan demikian, kebijakan UN tidak dapat dijadikan standar untuk mengukur mutu pendidikan.

Penyajian materi pembelajaran yang akan dievaluasi melalui UN pun tidak didukung oleh metode dan model pengajaran yang tepat. Metode pembelajaran itu lebih merupakan model pengajaran yang monologis dengan metode ceramah.

Diperlukan kecermatan yang sangat tinggi dalam menciptakan cara atau metode pembelajaran dengan model pembelajaran yang sesuai dan yang tidak kalah pentingnya ialah pemantauan berkesinambungan terhadap kegiatan belajar mengajar melalui penilaian berbasis kelas. Alokasi waktu dalam kaitan dengan organisasi materi dan organisasi pengalaman belajar perlu mendapat pertimbangan yang sangat cermat agar tidak terjerumus dalam "dosa" kurikulum masa lalu yang mengekang pengembangan diri pribadi siswa secara menyeluruh. Pendekatan ini menghantar ke pemberlakuan desentralisasi di tingkat kelas sebagaimana digagaskan oleh Silverius (1999).

Dalam semua kurikulum pendidikan, guru adalah the man behind the gun (manusia di balik senjata). Diperlukan kreativitas guru untuk mengisi senjata itu dan membidiknya sedemikian rupa sehingga mampu dengan cermat dan tepat mengena sasarannya secara efektif dan efisien. Keberhasilan kurikulum lebih banyak ditentukan oleh guru. Materi kurikulum, terutama untuk mata pelajaran dasar, di seluruh dunia pada dasarnya sama. Yang membedakannya adalah cara guru mengajar di depan kelas dan justru inilah yang lebih menentukan kualitas pendidikan.

Dalam kurikulum dan pembelajaran di kelas dibutuhkan pola pengajaran yang lebih interaktif dengan peran yang lebih besar pada siswa. Guru berperan sebagai fasilitator, dan bukan sebagai penceramah atau pengajar. Sebagai fasilitator, guru harus kreatif mengelola proses mengajar di 
kelas dengan menciptakan kondisi kelas yang hidup dan menarik, menciptakan suasana belajar yang rileks, bervariasi, dan menggelitik rasa ingin tahu, mengoptimalkan daya pikir anak didik melalui dengar, lihat, dan rasakan, serta mengembangkan nalar kritis dan mampu secara kreatif menemukan problem solving.

Selain keragaman dalam hal kecerdasan, siswa pun memiliki keragaman yang lain, seperti latar belakang, pengalaman belajar, cara belajar, dan lain-lain. Dengan demikian, metode yang digunakan dalam kegiatan belajar-mengajar pun harus bervariasi, benar-benar multicara, multiarah, dan tidak uniform. Memberi kesempatan kepada siwa untuk berpikir dan belajar sesuai kemampuannya adalah pilihan paling hakiki dalam proses belajar. Posisi guru yang paling luhur dalam era paradigma baru ini adalah sebagai fasilitator. Siswa dapat diberdayakan untuk memperoleh ilmu pengetahuan dari lingkungan di mana ia hidup dan berada dengan memberikannya kemampuan menguasai teknik membelajarkan diri secara independen.

Ketentuan penyesuaian kegiatan belajar mengajar dengan kompetensi masing-masing siswa merupakan konsep dasar yang melandasi pola pembelajaran yang patut diciptakan dalam rangka pelaksanaan desentralisasi pendidikan di tingkat kelas sebagaimana digagaskan oleh Silverius (1999).

Faktor lain ialah mengenai jawaban terhadap soal, khususnya pilihan ganda. Keberhasilan siswa menjawab pertanyaan bisa karena memang mengetahui jawabannya, tetapi bisa juga faktor kebetulan. Soal yang diujikan berbentuk multiple choice atau pilihan ganda sehingga dalam menjawab soal, peserta ujian tinggal memilih dari jawaban yang sudah ada. Dapat terjadi bahwa penulis soal tidak cermat sehingga soal yang ditulisnya bisa diketahui jawabannya, bahkan oleh siswa yang tidak belajar sekali pun.

Spekulasi semacam itu tidak bisa terjadi pada soal berbentuk isian atau uraian. Hanya siswa yang sudah mempelajari dan memahami materi dapat mengerjakan soal sedangkan yang sebaliknya tidak akan mampu menjawab soal. Dengan kata lain, model soal dapat menggambarkan "kemampuan siswa." Situasi serupa terjadi pula pada bentuk soal analisis kasus, analisis hubungan antarhal, dan melengkapi berganda. Bahkan, pada bentuk melengkapi berganda siswa dapat menjawab soal tanpa harus membaca optionnya. Kalau siswa dapat menjawab soal dengan benar tanpa penguasaan atau pemahaman materi soal berarti diperoleh hasil ujian yang tidak memberikan informasi sejati mengenai kompetensi siswa.

Kedua, penilaian yang dilakukan dalam UN tidak memperhatikan keragaman potensi daerah dan peserta didik. Menurut Pasal 36 ayat 2 UU Sisdiknas, kurikulum harus dikembangkan dengan prinsip diversifikasi (kemajemukan) sesuai dengan satuan pendidikan, potensi daerah, dan peserta didik, namun kebijakan tersebut diabaikan UN dengan melakukan penilaian pendidikan tanpa memperhatikan keberagaman potensi daerah dan peserta didik. Menelusuri hasil UN dalam perkembangan dari tahun ke tahun tampak hasil yang sangat beragam. Keragaman itu pula dijadikan sebagai landasan pemilihan cara merealisasikan suatu kebijakan. Sebagai contoh, komitmen yang diminta dari pemerintah daerah dalam hal pendidikan gratis diselaraskan dengan kebutuhan dan kemampuan masing-masing wilayah/daerah. Sanksi yang diberikan kepada kepala sekolah atau pihak terkait lainnya yang tidak melaksanakan pendidikan gratis ditetapkan oleh wilayah bersangkutan. Ditetapkan bahwa Departemen Pendidikan Nasional bakal memberikan sanksi kepada sekolah, khususnya SD dan SMP, yang tidak menerapkan pendidikan gratis. Kewenangan bentuk sanksi diserahkan kepada masing-masing daerah sesuai dengan peraturan daerahnya (Perda). Perda di setiap daerah pasti berbeda sesuai keragaman situasi dan kondisi wilayah daerah sendiri. Dengan adanya perda sebagai aturan hukum yang memayungi pelaksanaan pendidikan gratis maka sekolah yang tidak dapat menerapkan pendidikan gratis bakal terkena sanksi. Setiap daerah memiliki potensi dan kebutuhan beragam. Karena keragaman potensi dan kebutuhan masingmasing wilayah, jangan sampai kebijakan sekolah menimbulkan polemik di masyarakat.

Hal yang sama pun semestinya diberlakukan pada kebijakan penilaian dalam UN. Ternyata, pengalaman sampai sekarang ini memperlihatkan pelanggaran yang dilaksanakan oleh penye- 
lenggara UN. UN tampaknya sudah sesuai dengan keragaman daerah, namun perlu dicermati keragaman itu dipaksakan dari pusat yang menyiapkan bahan soal yang "beragam". Daerah diminta memilih dari keberagaman berkas ujian itu untuk digunakan di daerahnya sendiri. Hal itu adalah suatu pemaksaan untuk memilih satu dari lima sampai tujuh berkas ujian yang telah disiapkan kendatipun itu sebetulnya belum sepenuhnya sesuai dengan keadaan di sekolah wilayahnya sendiri.

Ketiga, hak guru untuk melakukan evaluasi hasil belajar peserta didiknya diambil alih oleh pemerintah dengan diberlakukannya UN. Hal ini melanggar Pasal 39 ayat 2 UU Sisdiknas yang menyatakan bahwa "Pendidik merupakan tenaga profesional yang bertugas merencanakan dan melaksanakan proses pembelajaran, menilai hasil pembelajaran..."

Dengan berlakunya UU Nomor 22, Tahun 1999 tentang otonomi daerah (otoda), maka terjadi perubahan berbagai kewenangan Pemerintah Pusat (Depdiknas) dalam berbagai hal, khususnya yang berkaitan dengan pendidikan. Kebijakan sentralistik yang selama ini dan sampai sekarang masih diterapkan dalam pola dan sistem top down memberikan dampak antara lain keterbatasan kewenangan kepala sekolah dalam mengelola sumber daya pendidikan sekolah yang dipimpinnya. Gaya panutan "menurut petunjuk bapak presiden" masih bercokol pada para kepala sekolah sehingga membiarkan kewenangannya mengelola sekolah dirampas oleh atasan birokrasinya. Atas situasi seperti ini maka kemampuan manajemen kepala sekolah dalam mengembangkan program pendidikan tersendat dan menjadi belum seoptimal yang semestinya. Hal ini lebih jauh berdampak pada kurang memadainya imbalan yang seharusnya diberikan kepada guru yang telah dinilai profesional dalam karya dan pengabdiannya di kelas. Alasan klasik yang selalu dilontarkan ialah pola anggaran yang tidak dapat dikendalikan oleh masing-masing wilayah, termasuk sekolah. Dampak semua peristiwa tersebut di atas ditunjang pula oleh keterbatasan peran serta masyarakat dalam pengelolaan sekolah.

Guna solusi dan perbaikan pola pikir dan pola tindak di atas diperlukan reformasi pengelolaan pendidikan yang diarahkan untuk dapat terciptanya kondisi yang desentralistik, baik pada tatanan birokrasi maupun pengelolaan sekolah. Khusus pada tingkat sekolah, melalui otonomi yang luas, partisipasi masyarakat perlu ditingkatkan terutama dalam hal perencanaan dan pengelolaan program sekolah melalui konsep manajemen berbasis sekolah.

Penerapan manajemen berbasis sekolah akan mampu "memberdayakan" sekolah, terutama sumber daya manusianya, sehingga kepala sekolah, guru, karyawan, peserta didik, orang tua peserta didik, dan masyarakat sekitarnya menggunakan kewenangan, flek-sibilitas, dan sumber daya lain untuk memecahkan persoalan yang dihadapi oleh sekolah yang bersangkutan. Manajemen pendidikan sentralistis yang selama ini dianut dan dipraktikkan mengakibatkan pengambilan keputusan oleh pusat dengan birokrasi yang berbelit tidak sesuai dengan kebutuhan sekolah padahal sekolah merupakan lembaga yang paling memahami permasalahan di sekolahnya sendiri. Dominasi birokrasi yang berbanding terbalik dengan tanggung jawab profesional membuat kreativitas sekolah, terutama guru menjadi terpasung, serta kehilangan jiwa kependidikannya. Oleh sebab itu, diperlukan suatu keberanian untuk mengadakan perubahan positif di sekolah. Perubahan itu akan terjadi jika semua warga sekolah mempunyai sense of belonging atau rasa memiliki yang berasal dari kesempatan berpartisipasi dalam merumuskan perubahan dan keluwesan untuk mengadaptasikannya terhadap kebutuhan individu sekolah. Apabila perubahan ini terwujud maka kualitas pendidikan pun akan beranjak naik sampai ke titik yang dicita-citakan. Dengan demikian, kualitas pendidikan akan meningkat dan terbuka kesempatan bagi guru dan kepala sekolah untuk berkreasi lebih intensif dalam sistem yang lebih demokratis yaitu manajemen berbasis sekolah. (Hadiyanto dan Subijanto, 2002).

Keempat, dalam kaitannya dengan mutu pendidikan, UN hanya melakukan evaluasi terhadap peserta didik sedangkan menurut Pasal 57 ayat 2 UU Sisdiknas, mutu pendidikan seharusnya didasarkan pada evaluasi yang dilakukan terhadap peserta didik, lembaga, dan program pendidikan. Keterpaduan komponen 
sumber daya manusia dalam lingkup sekolah tidak dapat dipisah-pisahkan jika menginginkan hasil optimal dari karya pendidik di tingkat sekolah. Tidak dapat dipungkiri kenyataan yang sampai sekarang masih tetap melanda pelaksanaan pendidikan ialah pemusatan pelaksanaan evaluasi pendidikan, khususnya UN, hanya pada peserta didik. Segala upaya dan cara diikhtiarkan untuk dilaksanakan kepada para peserta didik untuk mendapatkan keberhasilan UN. Segala cara dan upaya itu lebih banyak didasarkan atas gengsi dan hasrat tampil beda secara lebih meningkat dalam kompetisi antarsekolah.

Kelima, menurut Pasal 58 ayat 1 UU Sisdiknas, evaluasi hasil belajar dan penentuan kelulusan peserta didik dilakukan oleh pendidik/guru dan satuan pendidikan/sekolah. Kewenangan pendidik/guru dan sekolah termaksud telah dirampas melalui pelaksanaan UN.

Redaksi hukum ini sangat tepat karena pendidikan yang diterima oleh peserta didik diberikan oleh sekolah melalui para gurunya. Para guru lebih mengetahui, lebih mengenal, dan lebih memantau perkembangan pendidikan peserta didik. Hal itu diungkap Silverius (1999) dalam butir Abstrak. Silverius menulis: Kajian ini ingin mengulas perlunya desentralisasi secara mikro, khususnya di tingkat kelas. Konsep pendidikan yang banyak dianut para guru dan tenaga kependidikan berpusat pada hubungan satu arah antara guru dengan murid dengan guru sebagai sumber segala pengetahuan yang hendak dituangkan ke dalam diri murid yang dipandang sebagai gentong kosong yang tidak mahatahu atau bahkan yang mahatidaktahu. Konsep ini menjauhkan guru dan murid dari kehidupan realita dan masuk dalam suatu dunia kayalan. Oleh sebab itu, dipandang perlu adanya reformasi dalam bidang pendidikan. Bentuk reformasi yang ditawarkan dalam kajian ini ialah desentralisasi di tingkat kelas dan perubahan konsep pendidikan dari guru yang mahatahu menjadi guru sebagai mitra pembelajaran yang mengajar murid dan sekaligus juga diajar murid dengan masukan dari para muridnya. Dengan konsep ini para guru dan murid bersamasama memasuki dunia realita dan menjelajahinya bersama dan memanfaatkannya untuk pengembangan diri dan kepribadian masing-masing ke arah suatu kehidupan yang kritis dan kreatif.
Untuk pelaksanaan kegiatan pendidikan yang terdesentralisasi ke tingkat kelas maka kurikulum perlu disesuaikan dengan dunia sekitar sekolah. Untuk itu, diperlukan kurikulum yang disusun secara khusus sesuai kebutuhan setempat dan sekitar. Penyusunan kurikulum tidak lagi menjadi beban atau tanggung jawab Pusat Kurikulum tetapi menjadi tanggung jawab wilayah setempat atau bahkan sekolah yang bersangkutan.

Paparan yang dicuplik di atas memberikan indikasi yang berkaitan dengan evaluasi hasil belajar dan penentuan kelulusan peserta didik yang semestinya dilakukan oleh pendidik/guru dan satuan pendidikan/sekolah tetapi telah dirampas melalui pelaksanaan UN. Sebagaimana telah disebutkan di atas, perkembangan peserta didik dipantau setiap saat oleh guru yang mengajarnya. Peningkatan atau penurunan hasil belajar tiap insan didik diketahui oleh guru. Oleh karena itu, adalah lebih tepat dan lebih pantas apabila evaluasi terhadap perkembangan belajar insan didik itu dilakukan oleh sekolah melalui guru bersangkutan. Dalam kenyataan, hak ini telah dirampas oleh pihak lain yang memanfaatkannya melalui ujian sekolah yang tetap dipertahankan keberadaannya oleh pemerintah, cq Depdiknas.

Keenam, ditegaskan lebih lanjut bahwa kewenangan pemerintah dan pemerintah daerah melakukan evaluasi menurut Pasal 59 ayat $1 \mathrm{UU}$ Sisdiknas dapat dilakukan terhadap pengelola satuan, jalur, jenjang dan jenis pendidikan, dan bukan evaluasi terhadap hasil belajar peserta didik. Lagi-lagi hal ini berseberangan dengan nalar manusiawi yang pasti akan lebih menerima kedekatan keterkaitan antara hasil belajar peserta didik dengan evaluasi yang diberikan untuk memantau tingkat pengetahuan yang telah diterimanya. Dapat diterima tindakan evaluasi yang dilaksanakan oleh pemerintah dan pemerintah daerah dengan catatan bukan yang berkaitan dengan hasil belajar yang dipantau tingkat pencapaiannya melalui UN. Boleh saja dilakukan evaluasi asalkan evaluasi itu tentang pelaksanaan program yang dilakukan oleh pengelola satuan, jalur, jenjang, dan jenis pendidikan.

Ketujuh, Pasal 61 ayat 2 menyatakan, " Ijazah diberikan kepada peserta didik sebagai pengakuan terhadap prestasi belajar dan/atau 
penyelesaian suatu jenjang pendidikan setelah lulus ujian yang diselenggarakan oleh satuan pendidikan yang terakreditasi". Kewenangan pendidik/guru dan sekolah termaksud telah dirampas melalui pelaksanaan UN.

Ketimpangan ini pun berlaku sebagai konsekuensi dari penyimpangan yang terjadi dalam penyelenggaraan UN. Ujian sekolah disiapkan oleh pihak di luar guru sekolah masingmasing yakni pemerintah pusat, padahal semestinya dibuat oleh sekolah tersebut. Tindakan kebijakan ini akan menyimpangkan hasil ujian sekolah dari lingkup pembelajaran yang diterimakan guru kepada peserta didiknya. Lebih lanjut, keberhasilan pendidikan yang diterima oleh peserta didik yang dievaluasi oleh pihak yang semestinya tidak berwenang itu dihargai dalam suatu bentuk reward yang disebut ijazah. Dipertanyakan, apakah ijazah yang diterima oleh masing-masing lulusan UN itu tepat dan pantas jika ditilik dari alat evaluasi yang dipakai untuk mengukur hasil pembelajaran yang diragukan kualitasnya.

Disinyalir bahwa UN sering dimanfaatkan untuk kepentingan di luar pendidikan, seperti kepentingan politik dari para pemegang kebijakan pendidikan atau kepentingan ekonomi bagi segelintir orang. Oleh karena itu, tidak heran dalam pelaksanaannya ditemukan banyak kejanggalan sebagaimana telah dipaparkan di atas ditambah pula dengan jenis pelanggaran lain seperti kasus kebocoran soal, nyontek yang sistemik dan disengaja, merekayasa hasil pekerjaan siswa dan bentuk-bentuk kecurangan lainnya.

Seluruh paparan di atas bermuara pada pandangan menolak UN dan menciptakan kebijakan ujian sekolah yang berpotensi seperti yang selama ini diterapkan oleh UN.

\section{Ujian Ulang}

Dalam sejarah diselenggarakan UN selama ini, baru kali ini terjadi peristiwa yang mengharuskan pengulangan ujian seperti ini. Disinyalir, ada pihak-pihak yang membocorkan jawaban soal yang membuat peserta tidak lulus ujian.

Aturan yang tidak jelas menyebabkan UN ulang bagi siswa yang tidak lulus menimbulkan kontroversi berbagai pihak, terutama antara pemerintah dengan DPR RI. (http://www. kapanlagi.com/h/0000122859 print.html. Aturan Tak Jelas, Ujian Nasional Ulang Timbulkan Kontroversi)

Ketidakjelasan aturan mengakibatkan penyelenggaraan UN menjadi tidak jelas dasarnya. Tidak dapat diketahui apakah UN sebagai syarat tamat belajar atau untuk melanjutkan ke jenjang pendidikan selanjutnya.

Perlu ada peraturan yang jelas tentang tujuan diadakannya UN dan UN ulang sehingga tidak menimbulkan selisih pendapat yang menimbulkan kontroversi. Aturan yang dibuat sering tidak komunikatif, sehingga menimbulkan berbagai interpretasi. Oleh karena itu, aturan atau sistem penyelenggaraan UN perlu dibenahi.

Sekolah-sekolah yang diwajibkan menggelar pengulangan UN juga mempertanyakan mengapa bisa semua muridnya tidak lulus ujian. Menurut Hery Nugroho, Direktur Centre for Education Studies (CES) Jateng, kondisi tersebut, jelas merugikan siswa yang jujur dan tidak lulus. (http:// suaramerdeka.com/v1/index.php/read/cetak/ 2009/06/18/68368/Persiapan.Lebih.Matang. Hasil. Kelulusan.UN.Meningkat. Persiapan Lebih Matang Hasil Kelulusan UN Meningkat. 18 Juni 2009). Karena alternatif solusinya jika ingin melanjutkan pendidikan, harus mengikuti Ujian Nasional Pendidikan Kesetaraan (UNPK) Paket $C$ atau mengulang UN tahun depan. Tidak mengherankan jika para orang tua di SMKN 1 Temon, Kulonprogo DIY menolak hasil UN lalu dan menuntut UN ulang.

Dikatakannya, UN pengulangan bisa memicu daerah-daerah lain yang siswanya tidak lulus dengan alasan keadilan, menuntut perlakuan yang sama. Padahal jumlah siswa yang tidak lulus kalau ditotal mencapai ribuan. Supaya kejadian serupa tidak terulang, Badan Standar Nasional Pendidikan (BSNP) harus mengusut tuntas masalah tersebut dan memberikan sanksi yang setimpal terhadap pelaku kecurangan, sesuai dengan apa yang telah dilakukan. Selain itu BSNP juga harus tegas kalau memang aturannya tidak ada UN pengulangan, jangan diselenggarakan.

\section{Antara Kompetensi dan Kompetisi}

Tujuan meningkatkan standar kelulusan bagi peserta UN dilandaskan pada dua prinsip yang 
menjadi acuan. Pertama, sejauh mana kompetensi mempunyai pengaruh signifikan terhadap mutu lulusan. Kedua, bagaimana peningkatan mutu kelulusan dapat menjadi sarana kompetisi bagi siswa dan guru agar menghasilkan mutu kelulusan yang cakap dan berdaya saing di bidang kelulusan.

Pada sisi lain, ditinjau dari segi kompetisi, berbagai referensi baik nasional maupun internasional mengungkap bahwa sumber daya manusia Indonesia belum memiliki kualitas kompetitif yakni mutu yang berdaya saing. Kendatipun dinilai sangat memberatkan dengan peningkatan standar kelulusan mencapai angka 5,5 namun kebijakan peningkatan standar kelulusan tidak bisa ditawar lagi dan kalau ditunda atau diulur-ulur maka dunia pendidikan di tanah air akan terus didera stagnasi sementara bangsa lain sudah jauh melangkah. Seberapa tingginya kemampuan yang berdaya saing termaksud dapat disimpulkan dari tingkat kelulusan yang diperoleh atas dasar standar kelulusan yang tinggi. Bahwa lantaran tingginya standar kelulusan sehingga banyak peserta UN yang tidak lulus, harus diterima dengan berbesar hati dan berdada lapang sambil menanam tekad untuk semakin meningkatkan mutu kelulusan di tahun-tahun mendatang.

\section{Pembohongan Antargenerasi}

Mencermati kampanye pilpres 2009, salah satu isu yang ditonjolkan ialah pendidikan. Masyarakat diajak untuk secara sadar dan kritis mulai bangkit dan membangun dari sektor pendidikan menuju program bangsa ke depan. Dihadapkan pada pelaksanaan UN sebagai suatu komponen pendidikan nasional, masyarakat menyimak fakta dari tahun ke tahun bahwa UN dilakukan tanpa kejujuran. Alhasil, rentetan kebohongan demi kebohongan hasil-hasil pembangunan pun terjadi dan tidak mudah untuk dibetulkan. Telah terjadi pembohongan antargenerasi yang dilakukan oleh pemimpin yang tidak jujur. Oleh karena itu, masyarakat menuntut perlunya alih generasi kepemimpinan nasional yang bercirikan pemimpin yang jujur.

Pembohongan dimaksud juga ditegaskan oleh Surakhmad (Kompas, Selasa 23 Juni 2009). Surakhmad menyatakan kekecewaannya lantaran praksis pendidikan selama ini mengalami reduksi, baik sedari kebijakan hingga implementasi dan evaluasinya. Legalitas pendidikan tidak mendapat pengukuhan, malahan dilanggar begitu saja demi pemudahan pelaksanaannya secara praktispragmatis. Dicontohkannya, UN yang tidak menghargai diversifikasi wilayah antardaerah. Harus ada pembedaan dan penekanan khas masing daerah. Karenanya Indonesia tidak bisa diatur seragam, termasuk UN.

Dalam Pasal 58 ayat (2) Undang-Undang Nomor 20, Tahun 2003 disebutkan bahwa evaluasi peserta didik satuan pendidikan dan program pendidikan dilakukan oleh sebuah lembaga mandiri dan independen secara berkala, menyeluruh, transparan dan sistematik untuk menilai pencapaian standar nasional. Lembaga berwenang termaksud adalah BSNP, dengan tugas mengembangkan, memantau pelaksanaan, dan mengevaluasi standar nasional.

\section{Pemetaan Pendidikan Daerah}

Hasil ujian UN seyogianya dijadikan acuan oleh pemerintah daerah dalam penyusunan peta pendidikan di wilayahnya, terutama dalam kaitan dengan kompetensi guru. Dengan demikian, penyebaran tenaga guru tidak semata-mata didasarkan pada hitungan kuantitas, tetapi juga pada aspek kualitas. Hasil UN hendaknya memberi makna terhadap upaya peningkatan mutu pendidikan. Daerah-daerah mestinya sudah bisa membuat peta sekolah mana yang siswanya paling banyak lulus atau gagal UN. Dari situ bisa dievaluasi apakah karena jumlah gurunya yang kurang atau karena memang gurunya kurang kompeten.

Gambaran tentang tingkat keserasian antara tenaga pendidik dan peserta didik sangat diperlukan dalam pemetaan pendidikan. Pemetaan pendidikan merupakan hal mutlak. Tanpa adanya pemetaan, sulit diperoleh hasil evaluasi objektif terhadap perkembangan pendidikan di suatu daerah. Padahal, hasil evaluasi objektif itulah yang seharusnya menjadi dasar bagi penetapan arah kebijakan maupun program dari pemerintah pusat dan pemerintah daerah.

Kendali kelulusan secara nasional agaknya bukan cara yang tepat untuk melakukan pemetaan pendidikan karena tidak menyajikan secara komprehensif kemampuan akademik 
peserta didik. Standar kelulusan pada ujian nasional hanya didasarkan pada nilai siswa dalam menyelesaikan soal teoritis dan praktis, yang berarti bahwa standar kompetensinya hanya mengacu pada aspek kognitif semata-mata. Daripada mengukur kompetensi siswa melalui UN lebih baik mengukurnya dari ulangan-ulangan harian terhadap kemampuan/kompetensi siswa yang dilakukan guru dengan kontrol penuh dan berkesinambungan. Pemetaan kompetensi tidak bisa dilakukan hanya satu kali selama siswa mengikuti suatu jenjang pendidikan.

Yang lebih paham tentang kemampuan akademik peserta didik adalah gurunya sendiri. Guru pun lebih mengetahui tingkat dan dinamika perkembangan masing-masing peserta didiknya. Itulah sebabnya UU Nomor 20 tentang Sisdiknas secara tegas memposisikan guru sebagai pihak yang memiliki kewenangan penuh dalam mengevaluasi peserta didik dengan mengacu pada penguasaan tiga aspek, yaitu kognitif, afektif, dan psikomotorik.

Jika kendali kelulusan model yang digunakan dalam UN masih tetap diterapkan, hal itu bukan hanya akan menghabiskan anggaran yang miliaran rupiah tetapi justru akan melahirkan anomi pendidikan dan strategi yang dijalankan tidak akan bisa mencapai tujuan pendidikan yang diharapkan.

\section{Sikap Terhadap Ujian Nasional}

Pada awalnya tekanan UN hanya dirasakan oleh kalangan pemerhati pendidikan dan pengelola sekolah karena khawatir banyak siswanya tidak mampu memenuhi standar kelulusan, namun belakangan ini justru meluas sampai kepada masyarakat umum. Terdapat kesan bahwa pelaksanaan UN sebenarnya merupakan pembohongan publik. Tolok ukur kelulusan nasional senantiasa disiasati agar dapat meloloskan siswa dari nilai mati. Situasi ini menyiratkan bahwa penyelenggara dan birokrasi pendidikan bersikap tidak jujur dalam memberikan penilaian kepada peserta didik (ujian) sampai berupaya menyiasati nilai UN. Menyadari hakikat UN yang mengingkari berbagai ketentuan perundang-undangan dan tidak diserahterimakan kepada pendidik, dalam hal ini guru, berbagai pihak bertanya "ada apa di balik UN?"
Terhadap pertanyaan ini muncul berbagai tanggapan yang kesimpulannya dapat diklasifikasikan dalam tiga sikap yakni pertama, setuju UN dipertahankan; kedua, UN ditelaah ulang dan disempurnakan; dan ketiga, UN dihapus.

\section{Setuju Ujian Nasional Dipertahankan}

Walaupun UN bukan alat yang tepat untuk mengukur keberhasilan pendidikan didik di bidang akademik namun tetap diperlukan demi pengendalian terhadap mutu lulusan. Di samping itu, selain merupakan bentuk pertanggungjawaban kepada publik, UN memberikan umpan balik tentang kemampuan guru yang pada akhirnya memunculkan strategi peningkatan mutu mereka. Pencapaian standar kelulusan oleh peserta didik dapat dipandang sebagai bagian dari upaya untuk meningkatkan kualitas SDM. Gambaran tentang hal itu diperoleh dari UN yang menyajikan hasil evaluasi dan analisis ketuntasan materi yang disampaikan pada siswa.

Perlu disadari bahwa UN hanya merupakan salah satu alat ukur tingkat pencapaian prestasi belajar siswa dalam memenuhi standarisasi pendidikan di Indonesia. Di Indonesia kualitas pendidikan antarsekolah sangat bervariasi, dari yang tertinggi sampai yang terendah. Variasi yang sangat mencolok pun tampak dalam kualitas antara sekolah yang ada di kota dengan sekolah yang ada di desa. Variasi itu disebabkan oleh bermacam-macam sistem dan pengelolaannya. Otomatis output yang dihasilkan juga berbeda.

Atas dasar pertimbangan-pertimbangan itu UN tetap harus dilaksanakan. Kalau UN tidak dilaksanakan, justru akan membingungkan banyak pihak. Misalkan ada siswa dari suatu sekolah di daerah tertentu hendak berpindah ke sekolah di wilayah lain, dasar apa yang hendak dipakai sebagai standar penentu diterima tidaknya perpindahannya dan akan ditempatkan pada tingkat berapa. Diperlukan standar sekolah asal dengan standar sekolah yang dituju. Standar itu diperoleh melalui standar kelulusan UN.

Dengan demikian, UN harus tetap dipertahankan. 


\section{Setuju Ujian Nasional Ditelaah Ulang dan Disempurnakan}

UN tetap mutlak diperlukan namun perlu diadakan telaah mendalam untuk mendudukkan kembali UN pada tujuan dan fungsinya sehingga tujuannya tercapai tanpa ekses yang merugikan negara dan rakyat. Ditegaskan bahwa UN tetap diperlukan untuk menjaga standar mutu meskipun otonomi daerah di bidang pendidikan sudah dilaksanakan. Walaupun UN terkadang berperan menciptakan "pembunuhan" kreativitas proses pendidikan secara lebih universal namun tidak perlu dihapus tetapi diadakan koreksi terhadap penyelenggaraannya, mulai dari bentuk soal sampai praktiknya di lapangan.

UN dipandang begitu penting sehingga proses belajar selalu diarahkan pada bagaimana mengerjakan soal UN dengan efektif sehingga terjadilah kecenderungan gaya kepemimpinan sekolah tanpa memberi ruang terhadap kreativitas guru dalam mengajar. Pengajar pun disibukkan mengefektifkan waktu memberikan latihan mengerjakan soal UN sebagai ukuran pencapaian target kurikulum. Kondisi ini semakin diperburuk dengan bentuk soal UN yang (hampir) semua berupa pilihan ganda. Sudah sepatutnya pelaksanaan UN ditinjau ulang.

Disarankan agar UN diselenggarakan secara berkala. Gagasan ini merujuk pada empat hal, yaitu: a) konsekuensi penggunaan pendekatan belajar tuntas meniscayakan siswa dengan kecepatan belajar tinggi menyelesaikan pendidikannya lebih cepat, b) sesuai dengan Pasal 24 UU Sisdiknas, hak siswa untuk menyelesaikan masa pendidikan lebih awal seharusnya mendapat perhatian pemerintah, c) mengikuti pola perkuliahan di perguruan tinggi yang juga memberikan hak percepatan masa studi bagi mahasiswa, dan d) penyelenggaraan UN pada kursus atau pendidikan nonformal yang bisa dilakukan setiap empat bulan sekali. Dengan demikian, bila siswa -khususnya pada tingkat akhir- telah memenuhi standar kompetensi yang telah ditetapkan maka siswa bersangkutan dapat langsung mengikuti UN dengan asumsi setiap sekolah telah memiliki bank soal yang telah terstandar.

\section{Setuju Ujian Nasional Dihapus}

Pada awalnya himpitan UN hanya dirasakan oleh kalangan pengelola sekolah karena khawatir banyak siswanya tidak dapat memenuhi standar kelulusan tetapi belakangan justru masyarakat yang lebih sering menyorotinya. UN melahirkan kecurangan-kecurangan terhadap nilai UN dan kecurangan pelaporan-pelaporan pelaksanaan belajar dari daerah. UN menimbulkan kesenjangan pendidikan dan kesenjangan mutu pendidikan. Daerah tidak mungkin mengikuti standar UN dari pusat, karena sarana dan prasarana belajar-mengajar yang sangat terbatas dan pengalaman belajar anak-anak di seluruh Indonesia yang tidak sama. Siswa di pelosok tidak mungkin mendapatkan angka yang baik kecuali dipaksa untuk memanipulasi angka agar setaraf dengan sekolah yang bermutu.

Darmaningtyas, Pengamat pendidikan dari Lembaga Pengembangan Inisiatif Strategis untuk Transformasi, dalam buku Umberto Sihombing dan Suke Silverius (Oktober 2001) berjudul "Evaluasi Belajar Tahap Akhir Nasional (EBTANAS) Menjamin Mutu Pendidikan" mengatakan bahwa kalau UN dipertahankan berarti Depdiknas tidak punya kemauan untuk melaksanakan otonomi pendidikan. UN merupakan kebijakan pemerintah yang tidak adil di bidang pendidikan. Standar pendidikan yang dimiliki untuk masing-masing daerah tidak sama. Secara sosiologis, ujian nasional dapat berarti memarginalkan siswasiswa yang orang tuanya tidak mampu.

Ada praktisi pendidikan yang menyelami berbagai seluk beluk dan lika-liku UN mengatakan bahwa pelaksanaan UN itu sebenarnya merupakan pembohongan publik. Diduga bahwa selama ini penyelenggara dan birokrasi pendidikan tidak jujur dalam memberikan penilaian kepada peserta didik, sampai jauh mencoba menyiasati nilai akhir ujian. Diyakini bahwa tolok ukur kelulusan nasional selalu disiasati agar dapat meloloskan siswa dari jeratan angka mati.

Betapa pun santernya tuntutan penghapusan UN dengan berbagai macam rasional tersebut, namun pada kenyataannya tampak adanya keengganan "the men behind the ujian nasional" untuk menghapusnya. Disinyalir bahwa keengganan menghapus ujian nasional dipastikan bukan karena pertimbangan ilmiah, melainkan 
lebih disebabkan oleh sikap para birokrat yang sulit mengubah tradisi penilaian penyelenggaraan pendidikan dan lebih didasarkan pada aspek ekonomi karena UN adalah proyek pendidikan yang besar.

\section{Simpulan dan Saran}

\section{Simpulan}

Kritik dan kontroversi terhadap UN memerlukan solusinya. Kajian literatur telah menampilkan untaian butir-butir kritik termaksud. UN hanya mengukur aspek kognitif tanpa menyertakan aspek afektif dan aspek psikomotorik. Hal ini bertentangan dengan tujuan pendidikan. Dengan demikian, hasil UN tidak dapat dipakai sebagai penentu kelulusan kompetensi siswa. Hal ini diperkuat secara hukum melalui ketentuan dalam UU Sisdiknas.

Penyajian materi pembelajaran yang lebih berorientasi pada model pembelajaran yang monologis dalam bentuk ceramah tidak tepat, apalagi menyangkut materi yang berkaitan dengan aspek sikap dan aspek psikomotor. Kurikulum yang menjadi landasannya harus dikembangkan dengan prinsip diversifikasi (kemajemukan) sesuai dengan satuan pendidikan, potensi daerah, dan peserta didik, dan lebih jauh dipantau melalui evaluasi dalam UN.

Guru berhak melakukan evaluasi hasil belajar peserta didiknya. Dengan penetapan dan penerapan pola desentralistik, baik pada tatanan birokrasi maupun pengelolaan sekolah maka UN pun akan diarahkan agar hak guru melakukan evaluasi belajar peserta didiknya akan terakomodir.

Diperlukan keterpaduan komponen sumber daya manusia dalam lingkup sekolah agar dapat diperoleh hasil optimal dari karya pendidik di tingkat sekolah. Segala upaya dan cara diikhtiarkan untuk dilaksanakan kepada para peserta didik untuk mendapatkan keberhasilan ujian nasional. Oleh karena itu, adalah lebih tepat dan lebih pantas apabila evaluasi terhadap perkembangan belajar peserta didik dilakukan oleh sekolah melalui guru-gurunya. Sangat disayangkan apabila segala cara dan upaya itu lebih banyak didasarkan atas gengsi dan hasrat tampil beda secara lebih meningkat dalam kompetisi antarsekolah.
Sebagai pengakuan terhadap prestasi belajar dan/atau penyelesaian suatu jenjang pendidikan setelah lulus ujian maka ijazah diberikan kepada peserta didik yang bersangkutan. Dipertanyakan, apakah ijazah yang diterima oleh masing-masing lulusan UN itu tepat dan pantas jika ditilik dari alat evaluasi yang dipakai untuk mengukur hasil pembelajaran itu diragukan kualitasnya.

Disinyalir bahwa UN dimanfaatkan untuk kepentingan di luar pendidikan, seperti kepentingan politik dari para pemegang kebijakan pendidikan atau kepentingan ekonomi bagi segelintir orang. Jika hal itu benar dan terbukti maka sudah sepantasnya menolak UN dan menciptakan kebijakan ujian sekolah yang berpotensi seperti yang selama ini diterapkan oleh UN.

Berbagai pelanggaran UN terhadap ketentuan-ketentuan UU Sisdiknas memunculkan berbagai tanggapan yang dirangkum dan diklasifikasikan dalam tiga sikap yakni pertama, setuju UN dipertahankan; kedua, UN ditelaah ulang dan disempurnakan; dan ketiga, UN dihapus. Seluruh simpulan di atas menghadirkan pertanyaan: apakah kontroversi ujian nasional ini akan berlangsung sepanjang masa?

\section{Saran}

Terdapat keinginan dan bahkan tuntutan agar pelaksanaan evaluasi belajar di sekolah yang selama ini diselenggarakan oleh pemerintah, Pusat atau Daerah, dikembalikan kepada guru yang memiliki hak otoritas terhadap fungsi tersebut. Keinginan dan atau tuntutan itu telah dikokohkan oleh adanya peraturan perundangan yang mendukungnya. Oleh sebab itu, disarankan agar masing pihak terkait mengkaji hak dan kewajibannya dalam hal evaluasi belajar dan mengeksekusinya sebagaimana semestinya.

Kenyataan selama ini memperlihatkan bahwa kelulusan siswa didasarkan atas hasil momental UN di akhir jenjang yang hanya mengukur aspek kognitif tanpa menyertakan aspek afektif dan aspek psikomotorik. Hal ini bertentangan dengan tujuan pendidikan dan ketentuan UU Sisdiknas serta tidak dapat dijadikan standar untuk mengukur mutu pendidikan. Oleh sebab itu, disarankan kepada Depdiknas umumnya dan 
Puspendik Balitbang Depdiknas khususnya untuk berani memulai penyertaan aspek afektif dan psikomotor dalam UN yang nota bene dengan melibatkan para guru. Disarankan kepada pemerintah, cq Depdiknas, agar UN sebagai evaluasi terhadap perkembangan belajar peserta didik dilakukan oleh sekolah melalui guru-gurunya. Sebagai konsekuensinya, penetapan kelulusan peserta didik, penyusunan dan pemberian ijazah dilakukan oleh guru (baca: sekolah).
Adanya sinyalemen bahwa UN dimanfaatkan untuk kepentingan di luar pendidikan maka disarankan agar diberlakukan kebijakan ujian sekolah yang berpotensi seperti yang selama ini diterapkan oleh UN. Dengan demikian, UN bukan saja tidak dipertahankan atau ditelaah ulang melainkan dihapus.

\section{Pustaka Acuan}

Hadiyanto dan Subijanto. 2002. Pengembalikan Kebebasan Guru untuk Mengkreasi Iklim Kelas dalam Manajemen Berbasis Sekolah (MBS). Jurnal Pendidikan dan Kebudayaan No.039 - November 2002

http://suaramerdeka.com/v1/index.php/read/cetak/2009/06/18/68368/ Persiapan.Lebih.Matang.Hasil.Kelulusan.UN.Meningkat. Pendidikan. 18 Juni 2009. Persiapan Lebih Matang Hasil Kelulusan UN Meningkat) Diakses pada tanggal 9 Juli 2009

http://www.kapanlagi.com/h/0000122859 print.html. Aturan Tak Jelas, Ujian Nasional Ulang Timbulkan Kontroversi) Diakses pada tanggal 24 Juli 2009

Kompas. 2009. Sosok. Prof. Dr. Winarno Surakhmad MSc Ed. Selasa 23 Juni 2009.

Sihombing, Umberto dan Suke Silverius. Evaluasi Belajar Tahap Akhir Nasional (EBTANAS) Menjamin Mutu Pendidikan. Oktober 2001

Silverius, Suke. 1999. Desentralisasi Pendidikan di Tingkat Kelas. Jurnal Pendidikan dan Kebudayaan, Tahun Ke-5, No. 017, Juni 1999.

Undang-Undang Republik Indonesia No.20 Tahun 2003 tentang Sistem Pendidikan Nasional. Undang-Undang Nomor 22 Tahun 199 Tentang Otonomi Daerah 